\title{
Sensory quality and physicochemical properties of cassava roots as a function of technological management levels and harvest times
}

Qualidade sensorial e propriedades físico-químicas de raízes de mandioca em função dos níveis tecnológicos de manejo e épocas de colheita

Calidad sensorial y propiedades fisicoquímicas de las raíces de yuca en función de los niveles de manejo tecnológico y tiempos de cosecha

\begin{abstract}
The management practices used by farmers in cassava crops and the relationship with the sensory quality and physicochemical characteristics of cassava roots are still incipient. The objective of this work was to evaluate the productivity, sensory quality and physicochemical properties of cassava roots at harvest times and technological management levels. The study was conducted in Santa Maria, Rio Grande do Sul, Brazil, and the management practices employed in the field experiment corresponded to low, medium and high technological levels used by farmers in southern Brazil. The cultivar "Vassourinha" was used and the roots were harvested in the sixth, the seventh, and the eighth month after planting. The productivity, the physicochemical composition of the roots (dry matter, protein, lipid, ash, total fiber, resistant starch, and total starch) were determined, and the sensory analysis of the roots was performed. Technological levels did not influence the root productivity and it increased with the delay in the harvest season. There was an increase in protein at the high technological level and the highest content of starch was found in the roots harvested in the seventh month. Sensory acceptance of the roots showed greater acceptability in the sixth and seventh months after planting, with roots of a high technological level being preferred. Based on the results, the influence of management practices in the nutritional composition of the roots represents an important aspect for assessing the potential of the roots to be consumed or used in industrial processes.
\end{abstract}

Keywords: Manihot esculenta Crantz; Protein; Sensory acceptance; Soil fertility.

\section{Resumo}

As práticas de manejo utilizadas pelos agricultores nas lavouras de mandioca e a relação com a qualidade sensorial e as características físico-químicas das raízes da mandioca ainda são incipientes. O objetivo deste trabalho foi avaliar a produtividade, qualidade sensorial e propriedades físico-químicas das raízes da mandioca em diferentes épocas de colheita e níveis tecnológicos de manejo. O estudo foi realizado em Santa Maria, RS, Brasil, e as práticas de manejo empregadas no experimento de campo corresponderam aos níveis tecnológicos baixo, médio e alto utilizados pelos 
agricultores do sul do Brasil. Foi utilizada a cultivar "Vassourinha" e as raízes foram colhidas no sexto, no sétimo e no oitavo mês após o plantio. Foi determinada a produtividade, a composição físico-química das raízes (matéria seca, proteína, lipídio, cinza, fibra total, amido resistente e amido total) e realizada a análise sensorial das raízes. Os níveis tecnológicos não influenciaram na produtividade das raízes e aumentaram com o atraso da safra. Houve aumento da proteína em alto nível tecnológico e o maior teor de amido foi encontrado nas raízes colhidas no sétimo mês. A aceitação sensorial das raízes mostrou maior aceitabilidade no sexto e sétimo mês após o plantio, sendo preferidas raízes de alto nível tecnológico. Com base nos resultados, a influência das práticas de manejo na composição nutricional das raízes representa um aspecto importante para avaliar o potencial das raízes para serem consumidas ou utilizadas em processos industriais.

Palavras-chave: Manihot esculenta Crantz; Proteína; Aceitação sensorial; Fertilidade do solo.

\section{Resumen}

Las prácticas de manejo utilizadas por los agricultores en los cultivos de yuca y la relación con la calidad sensorial y las características fisicoquímicas de las raíces de yuca son aún incipientes. El objetivo de este trabajo fue evaluar el rendimiento, la calidad sensorial y las propiedades fisicoquímicas de las raíces de yuca en diferentes tiempos de cosecha y niveles tecnológicos de manejo. El estudio se llevó a cabo en Santa María, RS, Brasil, y las prácticas de manejo empleadas en el experimento de campo correspondieron a los niveles tecnológicos bajo, medio y alto utilizados por los agricultores del sur de Brasil. Se utilizó el cultivar "Vassourinha” y las raíces se cosecharon al sexto, séptimo y octavo mes después de la siembra. Se determinó el rendimiento, la composición fisicoquímica de las raíces (materia seca, proteína, lípidos, cenizas, fibra total, almidón resistente y almidón total) y se realizó el análisis sensorial de las raíces. Los niveles tecnológicos no influyeron en el rendimiento de raíces y aumentaron con el retraso en la cosecha. Hubo un aumento de proteína a un alto nivel tecnológico y el mayor contenido de almidón se encontró en las raíces cosechadas en el séptimo mes. La aceptación sensorial de las raíces mostró una mayor aceptabilidad en el sexto y séptimo meses después de la siembra, prefiriéndose las raíces de alto nivel tecnológico. Con base en los resultados, la influencia de las prácticas de manejo en la composición nutricional de las raíces representa un aspecto importante para evaluar el potencial de las raíces para ser consumidas o utilizadas en procesos industriales.

Palabras clave: Manihot esculenta Crantz; Proteína; Aceptación sensorial; Fertilidad del suelo.

\section{Introduction}

Cassava (Manihot esculenta Crantz), originally from South America, is now widely grown in tropical and subtropical regions of Asia, Africa, and Latin America, is considered the third most important source of energy in the diet of developing countries, after corn and rice, feeding around 800 million people worldwide (FAO, 2013; Zhu, 2015). Nigeria is the largest producer of cassava, with 56.0 million tons, followed by the Democratic Republic of Congo, which produced 33.8 million tons, and Brazil, occupies a prominent position in the world scenario of cassava production, being the fifth largest producer, with 21.5 million tons in the last five years (FAO, 2019).

Tolerance on drought associated with high efficiency in the use of nutrients (Fernandes et al., 2019) makes the crop key for both food security and subsistence for developing nations (Duque \& Setter, 2019). Cassava is a highly profitable crop and has good production in cultivation systems (Barata et al., 2021). Due to the flexibility of adapting the plant to various climatic conditions and good agronomic performance (Tironi et al., 2015; Gomes et al., 2020), most cassava producers consider that the crop requires little investment in management practices, which results in low productivity. The average productivity in Brazil in the last five years was $14.70 \mathrm{Mg} \mathrm{ha}^{-1}$ of roots (IBGE, 2019), a value significantly below its productive potential, which can reach 75 to $90.0 \mathrm{Mg} \mathrm{ha}^{-1}$ (Cock et al., 1979; Fermont et al., 2009).

Depending on the time of planting and harvesting of cassava, there are variations in environmental conditions during cultivation, which, in turn, determine the growth, development, and productivity of roots and the aerial part of the plant (Fagundes et al., 2009). They can cause changes in the texture and flavor of cassava roots when cooked. Also, the age of the plants is a major factor for their sensory acceptance (Franck et al., 2011). The quality of the roots is an important parameter that involves varied and complex factors, as they constitute a set of physical, chemical, and sensory characteristics (Pedri et al., 2018). In addition, properties such as color, texture, and appearance are important for consumer acceptance and encompass the sensory quality of the roots (Franck et al., 2011). 
Investment in fertilization (Rós et al., 2013; Fermont et al., 2009) and the duration of the growing season for cassava plants are directly related to root productivity (Fagundes et al., 2009). On the other hand, farmers and consultants believe that the practice of fertilization and the delay in harvest affect the taste and texture of the roots (Franck et al., 2011; Pedri et al., 2018; Tironi et al., 2019). However, there are no studies that relate the technological level of management and harvest time with the sensory aspects and chemical composition of the roots. Thus, in addition to meeting a practical demand from consultants, providing practical and reliable information for family farming, this work aimed to assess the productivity, the sensory quality, and physicochemical properties of cassava roots at harvest times and within different technological management levels.

\section{Methodology}

The experiment, which is quantitative in nature (Pereira et al., 2018), was planted in October, which is the recommended period for cultivation, in the agricultural year 2017/2018, in the experimental area of the Federal University of Santa Maria (29 $43^{\prime} \mathrm{S}, 53^{\circ} 43^{\prime} \mathrm{W}$ and alt. of 95m), in the municipality of Santa Maria, the Rio Grande do Sul, Brazil, one of the preferred regions for the cultivation of cassava in the Rio Grande do Sul (Tironi et al., 2019). The climate of the region, according to the Köppen classification, is Cfa type, humid subtropical with no defined dry season and hot summers (Kuinchtner and Buriol, 2001). The soil of the place is a transition between the São Pedro Mapping Unit (Arenic Red Dystrophic Argisol) and the Santa Maria Mapping Unit (Argissolo Bruno-Gray alitic umbrico) (Streck et al., 2008).

The cultivar used was "Vassourinha", considered the main cultivar of sweet cassava grown in southern Brazil (Tironi et al., 2019). In addition to having characteristics that favor the preference for producers and consumers, such as high productivity, ease of harvest, and good culinary quality. The experimental units were composed according to the methodology proposed by Tironi et al. (2015), consisting of plots $23.2 \mathrm{~m}$ long and $9.6 \mathrm{~m}$ wide, composed of 12 lines with 29 slots each with 5 to 7 buds, spaced between themselves and between lines at $0.8 \mathrm{~m}$, in a total area of $223 \mathrm{~m}^{2}$. The treatments were grouped into three levels of technological management practices according to the methods used to conduct cassava crops in southern Brazil. The technological levels were classed as High (LTH), Medium (LTM), and Low (LTL).

In LTH weed management was characterized by the application of the herbicide s-metolachlor in pre-emergence, at a dose of $1440 \mathrm{~g}$ a.i. ha ${ }^{-1}, 3.5 \mathrm{~kg} \mathrm{ha}^{-1}$ of $\mathrm{N}, 15 \mathrm{~kg} \mathrm{ha}^{-1}$ of $\mathrm{K}_{2} \mathrm{O}$, and $15 \mathrm{~kg} \mathrm{ha}^{-1}$ of $\mathrm{P}_{2} \mathrm{O}_{5}$ were applied, supplied by $75 \mathrm{~kg}^{-1}$ of fertilizer, in formulation 05-20-20 and $10 \mathrm{~kg} \mathrm{ha}^{-1}$ of $\mathrm{P}_{2} \mathrm{O}_{5}$ were supplied by Super Phosphate Simple in the planting operation, added with 147,22 $\mathrm{kg} \mathrm{ha}^{-1}$ of urea when the culture had 25-30 leaves (CQFS RS/SC, 2016). Correction of calcium (Ca) and magnesium ( $\mathrm{Mg}$ ) was not necessary because the levels of these nutrients in the soil were adequate for the crop. The control of weeds in the post-emergence of the crop occurred through mechanical control by weeding to maintain the crop without competition.

At LTM, no pre-emergent herbicide was applied and the control of weeds after the emergence of the crop occurred through mechanical control by three weeds during the crop cycle, being: 1) when the plants had 10 leaves, 2) when they had 25 to 30 leaves and the 3 ) performed 20 to 30 days after the second weeding. The fertilization management was carried out with a $50 \%$ reduction of the fertilizer used at the LTH, that is, 05-20-20 (37.5 kg ha-1) and Simple Super Phosphate (5 kg ha-1) in the planting operation and $73.61 \mathrm{~kg} \mathrm{ha}^{-1}$ of urea when the culture had 25-30 leaves. For LTL, no pre-emergent herbicide was applied and weed management after crop emergence was only two weedings during the crop cycle and no fertilization was carried out.

Three harvest seasons were performed: 1) period when the plants had the maximum leaf area index, characterized as 6 months after planting, 2) at 7 months after planting, and 3) at 8 months after planting, which represents the harvest season for a significant part of crops in southern Brazil. The root productivity $\left(\mathrm{Mg} \mathrm{ha}^{-1}\right)$ of each technological level was determined 
according to the methodology proposed by Tironi et al. (2015), which is expressed in values of fresh mass (MF) of the commercial roots $\left(\mathrm{Mg} \mathrm{ha}^{-1}\right)$. The productivity of the aerial part $\left(\mathrm{Mg} \mathrm{ha}^{-1}\right)$ was determined according to Streck et al. (2014).

A root is considered commercial when it has a diameter and length larger than or equal to 2 and $10 \mathrm{~cm}$, respectively (Schons et al., 2007). The roots with smaller dimensions were considered non-commercial and were not counted for the final productivity. Subsequently to the classification of commercial roots, they were weighed in an analytical balance to calculate productivity. Of these, ten roots were selected for the physical-chemical analyzes, whose preparation can be seen in Figure 1.

Figure 1. Flowchart of sample preparation for the physicochemical analysis of cooked cassava roots according to the technological level of management and harvest time after planting. Santa Maria, RS, Brazil.

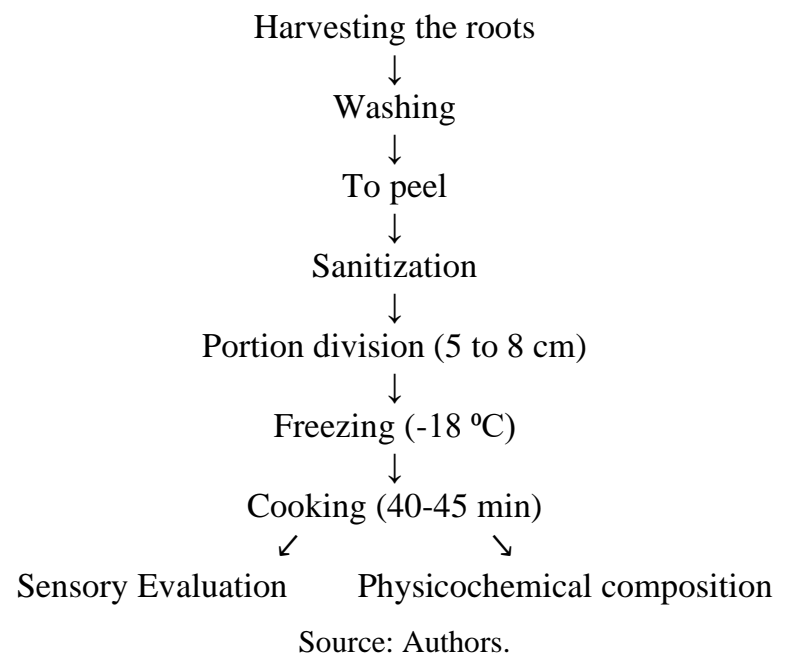

The evaluation of the characteristics and the physical-chemical composition of cassava roots was carried out after cooking, and the humidity, protein, ash, lipid, total fiber, total starch, and resistant starch contents were determined. To determine the humidity, the oven drying method $\left(105^{\circ} \mathrm{C} \pm 5^{\circ} \mathrm{C}\right)$ was used, based on the removal of water by heating until a constant mass was obtained (AOAC, 2011), whose values were expressed in dry matter (\%). Protein determination was performed using the micro-Kjeldahl method in which the total nitrogen content was evaluated and the conversion factor 6.25 was used for transformation into crude protein (AOAC, 2011). The method used to determine ash was the incineration in a muffle furnace $\left(550{ }^{\circ} \mathrm{C} \pm 5{ }^{\circ} \mathrm{C}\right)$, in which all organic matter was burned. The lipid content was determined using the BlighDyer method (1959). The total fiber was determined using the Ankom® fiber analyzer (200 Fiber Analyzer). Total starch and resistant starch were determined by the Resistant Starch assay kit (K-RSTAR - Megazyme International Ltd. Co. Wicklow, Ireland (2011)). All analyzes were performed in triplicates, and as the food is ingested in the wet form the results were expressed on a wet basis.

The sensory evaluation was carried out with the roots cooked in the three harvest seasons with the three technological levels, being conducted for three days, each day with a harvest season so that they remained the same period frozen. A group of 80 evaluators/day, volunteers and untrained participated in the evaluation, totaling 240 tasters. The attributes of appearance, color, aroma, flavor, texture, and global acceptance were verified by the affective acceptance test with a structured 7-point hedonic scale. The maximum value was represented by "I totally liked it" (grade 7) and the minimum by "I totally disliked it" (grade 1), the samples being offered individually and randomly (Lawless \& Heymann, 2010). The lower limit of the average for the acceptance of cassava roots was set at 4 . The roots were also evaluated by the ordering preference test, where the 
samples were requested to be ordered according to preference in decreasing order, with a value of "1" for preferred sample and “3” for preferred sample (Lawless \& Heymann, 2010).

For both analyzes, the samples were offered in a disposable plastic container, encoded with random three digits, served in individual booths and the tasters were also offered to a glass of water at room temperature to provide cleaning of the taste buds between sample evaluations (Ferreira et al., 2000). As it involves experimentation with human beings, this research was evaluated and approved by the Research Ethics Committee of the Federal University of Santa Maria on the opinion $\mathrm{n}^{\circ}$. 2.623.612.

Statistical analyzes were performed using the SAS software (Statistical Analysis System, 1999), version 9.0, through analysis of variance (ANOVA), Tukey means comparison tests $(\mathrm{p}<0.05)$, and linear regression for the quantitative variables. In the sensory analysis of Preference by Sorting, the data were analyzed by the Minimum Significant Difference (MSD) of the sum of orders for comparison $(p<0.05)$, based on Friedman nonparametric test and Newell and McFarlane's table (Ferreira et al., 2000).

\section{Results and Discussion}

Root productivity increased with the delay in harvesting, whose average values of technological levels ranged from 16.6 $\mathrm{Mg} \mathrm{ha}^{-1}$ when harvested at six months, to $35.7 \mathrm{Mg} \mathrm{ha}^{-1}$ when harvested in the eighth month after planting (Table 1).

Table 1. Yield of cassava roots and shoots, expressed in fresh mass - MF $\left(\mathrm{Mg} \mathrm{ha}^{-1}\right)$, depending on the technological levels of high, medium and low management, and harvest times (6,7 and 8 months after planting) in the experiment conducted in Santa Maria, RS, Brazil.

\begin{tabular}{|c|c|c|c|c|}
\hline \multirow{3}{*}{ Technological level } & \multicolumn{3}{|c|}{ Harvest season } & \multirow[b]{2}{*}{$p$ value } \\
\hline & 6 months & 7 months & 8 months & \\
\hline & \multicolumn{3}{|c|}{ Root productivity $\left(\mathrm{Mg} \mathrm{ha}^{-1}\right)$} & \\
\hline Low & $12.3^{\mathrm{a} 1}$ & $26.5^{\mathrm{a}}$ & $35.0^{\mathrm{a}}$ & $<0.05$ \\
\hline Medium & $18.9^{\mathrm{a}}$ & $31.0^{\mathrm{a}}$ & $35.3^{\mathrm{a}}$ & $<0.05$ \\
\hline High & $13.5^{\mathrm{a}}$ & $29.3^{\mathrm{a}}$ & -2 & -2 \\
\hline \multirow[t]{2}{*}{ Average } & 14.9 & 28.9 & 35.2 & \\
\hline & \multicolumn{3}{|c|}{ Shoot productivity $\left(\mathrm{Mg} \mathrm{ha}^{-1}\right)$} & \\
\hline Low & $8.9^{\mathrm{b}}$ & $8.7^{\mathrm{b}}$ & $7.5^{\mathrm{b}}$ & ns \\
\hline Medium & $12.1^{\mathrm{b}}$ & $12.0^{\mathrm{b}}$ & $17.8^{\mathrm{a}}$ & $<0.05$ \\
\hline High & $17.3^{\mathrm{a}}$ & $25.2^{\mathrm{a}}$ & $19.0^{\mathrm{a}}$ & $<0.05$ \\
\hline Average & 12.8 & 15.3 & 14.8 & \\
\hline
\end{tabular}

${ }^{1}$ Means followed by the same lower case letter in the column do not differ by Tukey test $(\mathrm{p}<0.05) .{ }^{2}$ Lost treatment. ns $=$ not significant. Source: Authors.

The permanence of plants in the field causes greater accumulation and translocation of photoassimilates to the reserve organs, the roots (Taiz \& Ziegler, 2013). Similar results were found by Borges et al. (2002), in Cruz das Almas - Bahia, where the productivity increased from $15.1 \mathrm{t} \mathrm{ha}^{-1}$, in the eighth month, to $21.5 \mathrm{t} \mathrm{ha}^{-1}$ in the 12th month. Alves et al. (2008) in a study carried out in Roraima, found productivity of fresh roots varying $27.7 \mathrm{Mg} \mathrm{ha}^{-1}$ at seven months to $50.4 \mathrm{Mg} \mathrm{ha}^{-1}$ at 13 months. The increase in productivity is since cassava is a perennial plant, and so the longer lasts the cycle in a subtropical environment, the greater is the production of tuberous roots (Fagundes et al., 2009). Technological levels did not influence root productivity in any harvest season (Table 1).

This is due to the soil in the experimental area having nutrient contents (potassium, calcium, magnesium, and phosphorus) considered high (CQFS RS/SC, 2016) and with a low weed seed bank; thus the medium and high technological levels did not respond to fertilization and weed control. Cassava productivity response to fertilization depends on soil fertility 
levels, that is, when grown on soils with medium to high fertility, there is little or no response to fertilization (Tironi et al., 2019). In soils with low fertility, however, the crop shows an increase in productivity, when fertilizers are used (Rós et al., 2013). The association between low soil fertility, water stress, and inadequate weed management during the development cycle can limit the production of cassava roots by up to $5.7 \mathrm{Mg} \mathrm{ha}^{-1}$ (Fermont et al., 2009).

The productivity of the aerial part of the plants (Table 1) showed a difference between the harvest times in the LTH and the LTM, and in all harvest times, the highest yields were found in the LTH. This is due to management practices and the application of fertilizers, mainly nitrogen, which favored the growth of the leaf area (Tironi et al., 2019). However, it is observed that from the seventh to the eighth month there was a decrease in the production of aerial parts, more accentuated in the LTH, given that due to the growth of the aerial part there was greater shading of the leaves, accelerating the natural senescence of the plants, a process that can also be verified when there is an increase in planting density of cassava (Streck et al., 2014).

The dry matter (DM) values (Table 2) are within ranges of variations cited in the literature (23\% to $38 \%$ ) as suitable for cassava roots (Rimoldi et al., 2006; Franck et al., 2011).

Table 2. Physicochemical composition of cooked cassava roots according to the high, medium and low technological levels of management and harvesting times (6, 7 and 8 months after planting). Santa Maria, RS, Brazil.

\begin{tabular}{|c|c|c|c|}
\hline \multirow{2}{*}{ Technological level } & \multicolumn{3}{|c|}{ Harvest season } \\
\hline & 6 months & 7 months & 8 months \\
\hline \multicolumn{4}{|c|}{ Dry matter $(\%)$} \\
\hline Low & $28.3^{\mathrm{aB} 1}$ & $33.3^{\mathrm{abA}}$ & $35.5_{\mathrm{aA}}$ \\
\hline Medium & $29.4^{\mathrm{aB}}$ & $35.9^{\mathrm{bA}}$ & $30.1^{\mathrm{bB}}$ \\
\hline High & $26.4^{\mathrm{aA}}$ & $30.1^{\mathrm{aA}}$ & $28.2^{\mathrm{bA}}$ \\
\hline \multicolumn{4}{|c|}{ Protein $(\%)$} \\
\hline Low & $0.9^{\mathrm{aA}}$ & $0.8^{\mathrm{aA}}$ & $0.4^{\mathrm{bB}}$ \\
\hline Medium & $0.7^{\mathrm{aA}}$ & $0.7^{\mathrm{aA}}$ & $0.8^{\mathrm{bA}}$ \\
\hline High & $0.9^{\mathrm{aA}}$ & $1.0^{\mathrm{aA}}$ & $1.7^{\mathrm{aA}}$ \\
\hline \multicolumn{4}{|c|}{ Ashes (\%) } \\
\hline Low & $0.7^{\mathrm{aA}}$ & $0.5^{\mathrm{aA}}$ & $0.5^{\mathrm{aA}}$ \\
\hline Medium & $0.5^{\mathrm{baA}}$ & $0.4^{\mathrm{aA}}$ & $0.4^{\mathrm{aA}}$ \\
\hline High & $0.5^{\mathrm{bA}}$ & $0.5^{\mathrm{aA}}$ & $0.5^{\mathrm{aA}}$ \\
\hline \multicolumn{4}{|c|}{ Lipid (\%) } \\
\hline Low & $0.4^{\mathrm{bA}}$ & $0.5^{\mathrm{aA}}$ & $0.4^{\mathrm{aA}}$ \\
\hline Medium & $0.5^{\mathrm{aA}}$ & $0.3^{\mathrm{bB}}$ & $0.3^{\mathrm{aBA}}$ \\
\hline High & $0.5^{\mathrm{bA}}$ & $0.5^{\mathrm{aA}}$ & $0.5^{\mathrm{aA}}$ \\
\hline \multicolumn{4}{|c|}{ Total Fiber (\%) } \\
\hline Low & $1.9^{\mathrm{aA}}$ & $1.5^{\mathrm{aBA}}$ & $1.7^{\mathrm{aB}}$ \\
\hline Medium & $1.4^{\mathrm{bA}}$ & $1.6^{\mathrm{aA}}$ & $1.5^{\mathrm{aA}}$ \\
\hline High & $2.0^{\mathrm{aA}}$ & $1.6^{\mathrm{aB}}$ & $1.6^{\mathrm{aB}}$ \\
\hline \multicolumn{4}{|c|}{ Resistant Starch (\%) } \\
\hline Low & $4.20^{\mathrm{aA}}$ & $4.71^{\mathrm{aA}}$ & $5.11^{\mathrm{aA}}$ \\
\hline Medium & $3.71^{\mathrm{aB}}$ & $4.38^{\mathrm{aAB}}$ & $5.13^{\mathrm{aA}}$ \\
\hline High & $3.13^{\mathrm{aB}}$ & $4.72^{\mathrm{aA}}$ & $5.25^{\mathrm{aA}}$ \\
\hline \multicolumn{4}{|c|}{ Total Starch (\%) } \\
\hline Low & $23.86^{\mathrm{aB}}$ & $31.81^{\mathrm{aA}}$ & \\
\hline Medium & $25.43^{\mathrm{aB}}$ & $32.12^{\mathrm{aA}}$ & $27.31^{\mathrm{abA}}$ \\
\hline High & $21.90^{\mathrm{aA}}$ & $26.32^{\mathrm{bA}}$ & $23.45^{\mathrm{bA}}$ \\
\hline
\end{tabular}

${ }^{1}$ Medias followed by the same lowercase letter in the column and uppercase in the row do not differ, using the Tukey test ( $p<0.05$ ). All results are expressed on a wet basis. Source: Authors.

When harvested in the sixth month after planting, the roots had the lowest dry mass content, and in that period there was greater availability of water in the soil, and as a consequence, greater absorption by the roots, due to the higher rainfall in 
the period preceding the harvest. In the seventh and eighth months, rainfall accumulation decreased respectively, and consequently, the dry matter content of the roots increased. The levels of DM in the LTH did not show differences in the harvest times studied since the greater fertilization and the better weed control provided greater accumulation of DM in the roots (Table 2).

When harvested in the sixth month after planting, the roots had the lowest dry mass content, and in that period there was greater availability of water in the soil, and as a consequence, greater absorption by the roots, due to the higher rainfall in the period preceding the harvest. In the seventh and eighth months, rainfall accumulation decreased respectively, and consequently, the dry matter content of the roots increased. The levels of DM in the LTH did not show differences in the harvest times studied since the greater fertilization and the better weed control provided greater accumulation of DM in the roots (Table 2).

The roots showed low levels of protein, which varied from $0.4 \%$ to $1.7 \%$ (Table 2), which was expected since this product is considered an essentially energetic food due to its high carbohydrate content (Souza et al., 2008; Tagliapietra et al., 2019). The protein content remained the same between harvest times and technological levels in the sixth and seventh months after planting. In the eighth month, the protein content of LTL decreased, when compared to previous harvest seasons, probably because it did not receive nitrogen fertilization as a cover.

In the eighth month, at the high (LTH) and low (LTL) technological levels, a constant increase in protein content was observed, probably due to the greater availability of nitrogen in the soil, resulting from the fertilization carried out in the development stage of early accumulation starch, resulting in increased concentration of protein in the roots with the delay of the harvesting season (Table 2). The rise in protein levels may also be related to the application of potassium (K) in basic fertilization. Although $\mathrm{K}$ is not a basic component of proteins, it plays an important role in the production of amino acids necessary for protein synthesis (Donato et al., 2004).

A study that evaluated the productivity and influence of the harvesting season on the physicochemical characteristics of cassava roots found that only plants harvested after the eighth month of planting had protein levels above 1\% (Oliveira and Moraes 2009). Whilst cassava roots do not have very high protein content, they have high nutritional value protein (Ceni et al., 2009). In addition, the low protein content of cassava roots makes it a source of energy with low allergenic potential (Ceballos et al., 2006).

The contents of ash, fat, and total fiber were found in small amounts in the cassava roots (Table 2). No increase in fiber content was found with the age of the root, which contrasts with some authors who stated that the fiber content increases with the permanence of the plants in the crop. This causes changes in the texture and a delay in the cooking time of the roots (Borges et al., 2002; Franck et al., 2011). Since our study is carried out in a subtropical region, the crop development cycle is shorter (maximum of 8 months) than in tropical regions (12 months or more) and this may explain these differences in response for the same variable.

Regarding the resistant starch (RS) content, no difference was found in the accumulation between technological levels in any of the harvest seasons, with higher values with the delay in harvest. Considering that several digestive diseases are triggered by inadequate diets, the encouragement for the consumption of food containing RS, such as cassava root, is important to improve and promote the population's health (Fernandes et al. 2019). Regarding total starch, it was observed that the highest levels were found in the roots harvested in the seventh and eighth months after planting (Table 2). Therefore, the roots can be harvested from the seventh month of planting without generating losses about the accumulation of starch in the roots.

All the sensory acceptance averages obtained for cassava roots were higher than four, in other words, in no harvest season or any technology level the roots showed sensory characteristics rejected by consumers (Figure 2). 
Figure 2. Acceptance graphs, based on the evaluation of the taste, appearance, color, texture and aroma of cassava roots according to technological levels (LTL, LTM, LTH) and harvest times (6, 7 and 8 months). The continuous gray line in all graphs represents the acceptance limit established in four for sensory analysis.
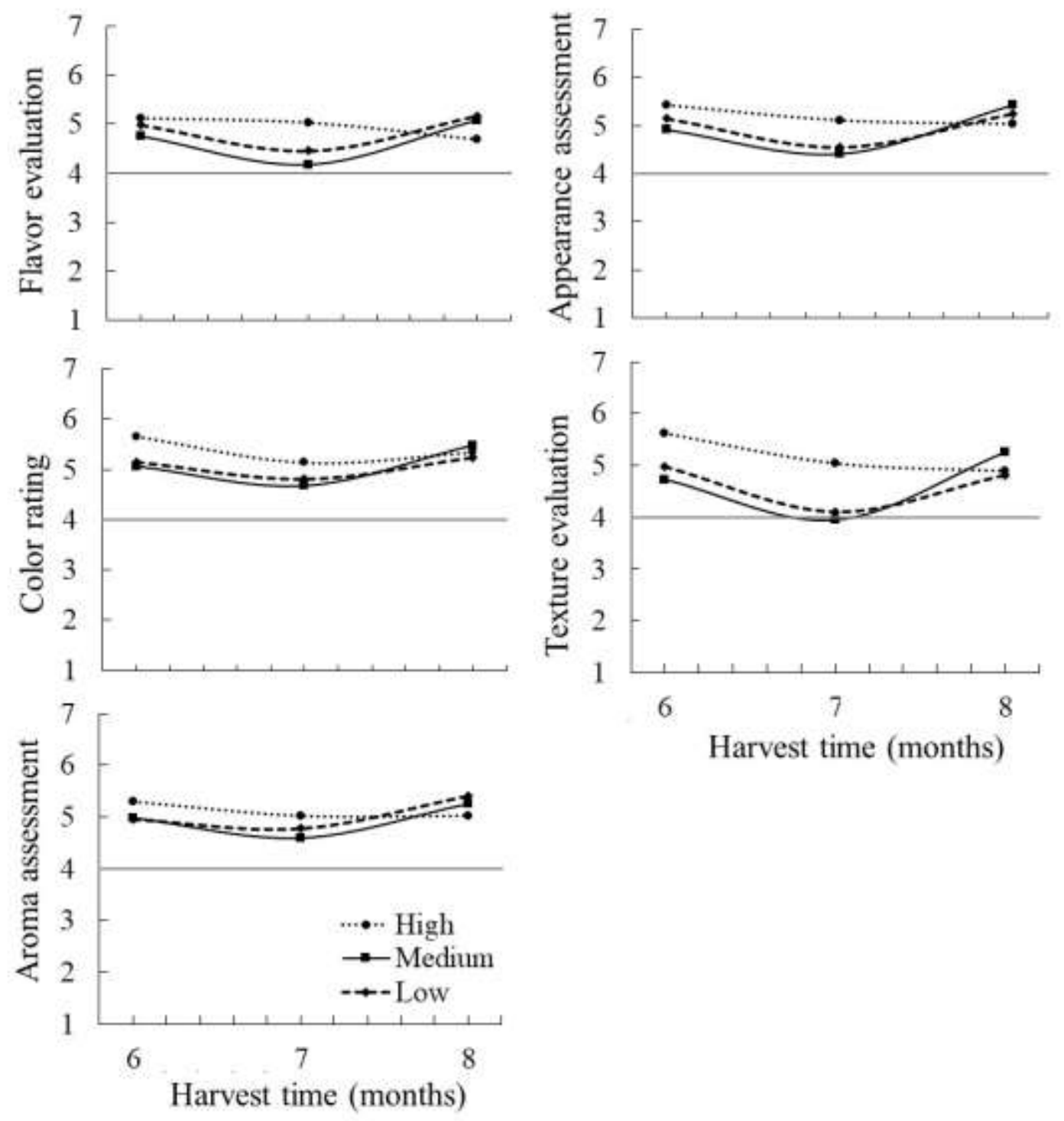

Source: Authors.

In relation to all the attributes evaluated (taste, appearance, color, texture and aroma), the high technological level showed greater acceptance for the harvest time in months six and seven. When cassava was harvested in the eighth month after planting, the acceptable values for the sensory attributes were very close at all technological levels. Similar results were found in a study by Talma et al. (2013), who evaluated sixteen cassava cultivars and found sensory acceptance averages higher than the acceptable limit in all cultivars.

The roots harvested at months six and seven differed significantly among the technological levels. For both months the high technological level was preferred to the others, confirming the results found in the sensory acceptance analysis (Table $4)$. 
Table 4. Results of the tasters' preference in relation to the cassava roots according to the time of harvest and technological levels.

\begin{tabular}{lccc}
\hline \multirow{2}{*}{ Technological level } & \multicolumn{3}{c}{ Harvest season } \\
\cline { 2 - 4 } & 6 months & 7 months & 6 months \\
\hline Low & $160^{\mathrm{c}}$ & $199^{\mathrm{c}}$ & $160^{\mathrm{ab}}$ \\
Medium & $191^{\mathrm{b}}$ & $164^{\mathrm{b}}$ & $141^{\mathrm{a}}$ \\
High & $127^{\mathrm{a}}$ & $117^{\mathrm{a}}$ & $179^{\mathrm{b}}$ \\
\hline
\end{tabular}

Sum of acceptance scores followed by the same letter in the column do not differ, considering $\mathrm{p}<5 \%$, based on Friedman nonparametric test and Newelle and McFarlane table (DMS = 30). Source: Authors.

When cassava competes with weeds, the process of deterioration of the pulp can be accelerated, be it microbial or physiological (Peressin, 2013), which may justify the better acceptance of LTH by the tasters. This might be the reason why LTH is at the technological level with the best management practices for these organisms.

Knowing the nutritional composition of cassava roots represents an important aspect for assessing the potential of roots to be consumed or used in industrial processes. In addition, these results clarify one of the main questions raised by consultants, demonstrating that the fertilization did not interfere negatively in the sensorial acceptance of the roots. The study demonstrated that the improvement of the management practices through fertilization and control of weeds does not interfere in root productivity.

\section{Conclusion}

Technological management levels do not influence root productivity and increase the production of the aerial part. There was an increase in the yield of cassava roots with the lengthening of the development cycle, in other words, with the delay in the harvest season. In the eighth month after planting, there was an increase in protein levels from LTL to LTH. The highest levels of starch were found in the seventh and eighth months after planting. The highest acceptability was of the roots harvested in the sixth and seventh months after planting, with the roots of LTH being preferred. However, more studies are necessary to verify if these results are maintained for other cultivars, other types of fertilization, and other harvest times.

\section{Acknowledgments}

The authors would like to thank the National Council for Scientific and Technological Development (CNPq) and the Coordination for the Improvement of Higher Education Personnel (CAPES), Financial Code 001, for providing scholarships and financial support for this work. The authors would also like to thank the students who are part of the Simanihot Team, who helped to conduct the field experiment.

\section{References}

Alves, J. M. A., Costa, F. A., Uchôa, S. C. P., Santos, C. S. V., Albuquerque, J. A. A., \& Rodrigues, G. S. (2008). Avaliação de dois clones de mandioca em duas épocas de colheita. Revista Agroambiente, 2, 15-24.

AOAC - Association of official analytical chemists. (2011). Official Methods of Analysis of AOAC International. USA, MD: Gaithersburg.

Barata, H. S., Gatti, V. C. M., Silva, C. R., Carvalho, F. I. M., Oliveira, J. T., Silva, J. N., Silva, V. F. N., \& Silva, P. A. (2021). The importance of agroeconomic characteristics for minimal cassava processing: A Review. Research, Society and Development, 7, e57110716904. http://dx.doi.org/10.33448/rsdv10i7.16904

Bligh, E. G. \& Dyer, W. J. (1959). A rapid method of total lipid extraction and purification. Canadian Journal of Biochemistry and Physiology, $37,911-917$. https://doi.org/10.1139/o59-099

Borges, M. F., Fukuda, W. M. G., \& Rossetti, A.G. (2002). Avaliação de variedades de mandioca para consumo humano. Pesquisa Agropecuária Brasileira, 37, 1559-1565. https://doi.org/10.1590/S0100-204X2002001100006 
Ceballos, H., Sánchez, T., Chávez, A. L., Iglesias, C., Debouck, D., Mafla, G., \& Tohme, J. (2006). Variation in crude protein content in cassava (Manihot esculenta Crantz) roots. Journal of Food Composition and Analysis, 19, 589-593. https://doi.org/10.1016/j.jfca.2005.11.001

Cock, J. H., Franklin, D., Sandoval, G., \& Juri, P. (1979). The ideal cassava plant for maximum yield. Crop Science, 19, 271-279. https://doi.org/10.2135/cropsci1979.0011183X001900020025x

CQFS-RS/SC - Comissão de Química e Fertilidade do Solo - RS/SC. Manual de calagem e adubação para os Estados do Rio Grande do Sul e de Santa Catarina. (2016). Sociedade Brasileira de Ciência do Solo. 376p.

Donato, V. M. T. S., Andrade, A. G., Souza E. S., França, J. G. E., \& Maciel, G. A. (2004). Atividade enzimática em variedades de cana-de-açúcar cultivadas in vitro sob diferentes níveis de nitrogênio. Pesquisa Agropecuária Brasileira, 39, 1087-1093. https://doi.org/10.1590/S0100-204X2004001100006

Duque, L. O. \& T. L. Setter. (2019). Partitioning index and non-structural carbohydrate dynamics among contrasting cassava genotypes under early terminal water stress. Environmental and Experimental Botany, 163, 24-35. https://doi.org/10.1016/j.envexpbot.2019.03.023

FAO - Food and Agriculture Organization of the United Nations. Production crop data. http://www.fao.org/faostat/en/\#data/QC.

FAO - Food and Agriculture Organization of the United Nations. Save and Grow: Cassava. A Guide to Sustainable Production Intensification. (2013). Rome.

Fermont, A. M., Van Asten, P. J. A., Titonell, P., Van Wijk, M. T., \& Giller, K. E. (2009). Closing the cassava yield gap: an analysis from smallholder farms in East Africa. Field Crops Research, 112, 24-36. https://doi.org/10.1016/j.fcr.2009.01.009

Fernandes, D. S., Santos, T. P. R., Fernandes, A. M., \& Leonel, M. (2019). Harvest time optimization leads to the production of native cassava starches with different properties. International Journal Biology Macromolecules, 132, 710-721. https://doi.org/10.1016/j.ijbiomac.2019.03.245

Ferreira, V. L. P., Almeida, T. C. A., Pettinelli, M. L. C. V., Silva, M. A. A. P., Chaves, J. B. P., \& Barbosa, E. M. M. (2000). Análise sensorial: testes discriminativos e afetivos. Campinas: SBCTA.127p.

Franck, H., M., Christian, A. Noel, P., Brigitte, D., Hounhouigan, D., Joseph, C. N., Mathurin, C. (2011). Effects of cultivar and harvesting conditions (age, season) on the texture and taste of boiled cassava roots. Food Chemistry, 126, 127-133. https://doi.org/10.1016/j.foodchem.2010.10.088

Gomes, D. A., Amaral, L. S., Ferreira, D. S. A., Moreira, G. R., Silva, F. G., Costa, M. L. L., Filho, M. C., Santos, A. L. P., Figueiredo, M. L. P., \& Pimentel, P. G. (2020). Caracterização de genótipos de mandioca por técnicas multivariadas. Research, Society and Development, 9, 1-14. http://dx.doi.org/10.33448/rsd-v9i7.4181

IBGE - Instituto Brasileiro de Geografia e Estatística. (2019). Levantamento sistemático da produção agrícola.

Kuinchtner, A. \& Buriol, G. A. (2001). Clima do estado do Rio Grande do Sul, segundo a classificação climática de Köppen e Thornthwaite. Disciplinarum Scientia, Série Ciências Exatas. 2, 171-182.

Lawless, H. \& Heymann, H. (2010). Sensory Evaluation of Food Science Principles and Practices. Ithaca. 626p.

Oliveira, M. A. \& Moraes, P. S. B. (2009). Características físico-químicas, cozimento e produtividade de mandioca cultivar IAC 576-70 em diferentes épocas de colheita. Ciência e Agrotecnologia, 33, 837-843. https://doi.org/10.1590/S1413-70542009000300024

Pedri, E. C. M., Rossi, A. A. B., Cardoso, E. S., Tiago, A. V., Hoogerheide, E. S. S. O., \& Yamashita, M. (2018). Características morfológicas e culinárias de etnovariedades de mandioca de mesa em diferentes épocas de colheita. Brazilian Journal of Food and Technology, 21: e2018073. https://doi.org/10.1590/1981-6723.07318

Pereira, A. S., Shitsuka, D. M., Perreira, F. J., \& Shitsuka, R. (2018). Metodologia da pesquisa cientifica. UFSM.

Peressin, V. A. (2013). Manejo integrado de plantas daninhas na cultura da mandioca. Instituto Agronômico. 54p.

Rimoldi, F., Soares, V. F. P., Vidigal, M. C. G., Clemente, E., Pequeno, M. G., Miranda, L., \& Kvitschal, M. V. (2006). Produtividade, composição química e tempo de cozimento de cultivares de mandioca de mesa coletadas no Estado do Paraná. Acta Science Agronomy, $28,63-69$.

Rós, A. B., Hirata, A. C. S., \& Narita, N. (2013). Produção de raízes de mandioca e propriedades química e física do solo em função de adubação com esterco de galinha. Pesquisa Agropecuária Tropical, 43, 247-254. https://doi.org/10.1590/S1983-40632013000300001

Schons, A., Streck, N. A., Kraulich, B., Pinheiro, D. G., \& Zanon, A. J. (2007). Emissão de folhas e início da acumulação de amido em raízes de uma variedade de mandioca em função da época de plantio. Ciência Rural, 37, 1586-1592. https://doi.org/10.1590/S0103-84782007000600013

Streck, N. A., Paula, G. M., Camera, C., Menezes, N. L., \& Lago, I. (2008). Estimativa do plastocromo em cultivares de soja. Bragantia, 67, 67-73. https://doi.org/10.1590/S0006-87052008000100008

Streck, N. A., Pinheiro, D. G., Zanon, A. J., Gabriel, L.F., Rocha, T.S.M. Souza, A. T., \& Silva, M. R. (2014). Efeito do espaçamento de plantio no crescimento, desenvolvimento e produtividade da mandioca em ambiente subtropical. Bragantia, 73, 407-415. https://doi.org/10.1590/1678-4499.0159

Tagliapietra, B. L., Zanon, A. J., Silva, M. N., Alves, A.F., Freitas, C. P. O., Tironi, L. F. Escalona, M. S. J., Cardoso, P., Santos, A. T. L., Tonel, G. P., Rodrigues, L. B., Richards, N. S. P. S., \& Streck, N. A. (2019). Mandioca para Alimentação Humana e Animal. Ed. GR, Santa Maria. 104p.

Taiz, L. \& Zeiger, E. (2013). Fisiologia vegetal. Porto Alegre. 952p.

Talma, S. V., Almeida, S.B., Lima, R. M. P., Vieira, H. D., \& Berbeet, P. A. (2013). Tempo de cozimento e textura de raízes de mandioca. Brazilian Journal of Food and Technology, 16, 133-138. http://dx.doi.org/10.1590/S1981-67232013005000016 
Research, Society and Development, v. 10, n. 10, e312101018849, 2021

(CC BY 4.0) | ISSN 2525-3409 | DOI: http://dx.doi.org/10.33448/rsd-v10i10.18849

Tironi, L. F., Uhlmann, L. O., Streck, N. A., Samboranha, F. K., Freitas, C. P. O., \& Silva, M. R. (2015). Desempenho de cultivares de mandioca em ambiente subtropical. Bragantia, 74, 58-66. http://dx.doi.org/10.1590/1678-4499.0352

Tironi, L. F., Zanon, A. J., Alves, A. F., Freitas, C. P. O., Santos, A. T. L., Cardoso, P., Tonel, G. P., Rodrigues, L. B., Tagliapietra, B. L., Silva, M. N., \& Streck, N. A. (2019). Ecofisiologia da Mandioca Visando Altas Produtividades. Ed. GR, 136p.

Zhu, F. (2015). Composition, structure, physicochemical properties, and modifications of cassava starch. Carbohydrate Polymers, 122, 456-480. https://doi.org/10.1016/j.carbpol.2014.10.063 